\title{
Investigation and Identification of Govkhoni Arg using Sat Light Images (Land Sat ETM+)
}

\author{
Abdolah Saif ${ }^{1}$, Maryam Marani-Barzani ${ }^{2}$, Kaveh Ostad-Ali-Askari ${ }^{3 *}$, Saeid Eslamian ${ }^{4}$, Amir $^{-}$ \\ Gandomkar ${ }^{5}$, Ahmad Khademolhoseiny ${ }^{5}$, Shahide Dehghan ${ }^{5}$, Mohsen Ghane $^{6}$, Vijay P. Singh ${ }^{7}$, \\ Nicolas R. Dalezios ${ }^{8}$, Yohannes Yihdego ${ }^{9}$ \\ ${ }^{I}$ Associate Professor, Department of Geography, Isfahan University, Isfahan, Iran \\ ${ }^{2}$ Department of Geography, University of Malaya (UM) ,50603 Kuala Lumpur, Malaysia \\ $3^{3 *}$ Department of Civil Engineering, Isfahan (Khorasgan) Branch, Islamic Azad University, Isfahan, Iran \\ ${ }^{4}$ Department of Water Engineering, Isfahan University of Technology, Isfahan, Iran \\ ${ }^{5}$ Department of Geography, Najafabad Branch, Islamic Azad University, Najafabad, Iran \\ ${ }^{6}$ Department of Civil Engineering, South Tehran Branch, Islamic Azad University, Tehran, Iran \\ ${ }^{7}$ Department of Biological and Agricultural Engineering \& Zachry Department of Civil Engineering, Texas A \\ and M University, 321 Scoates Hall, 2117 TAMU, College Station, Texas 77843-2117, U.S.A. \\ ${ }^{8}$ Laboratory of Hydrology, Department of Civil Engineering, University of Thessaly, Volos, Greece \& \\ Department of Natural Resources Development and Agricultural Engineering, Agricultural University of \\ Athens, Athens, Greece. \\ ${ }^{9}$ Snowy Mountains Engineering Corporation (SMEC), Sydney, New South Wales 2060, Australia. Geo \\ Information Science and Earth Observation (ITC), University of Twente, the Netherlands
}

*Corresponding Author: Dr. Kaveh Ostad-Ali-Askari, Department of Civil Engineering, Isfahan (Khorasgan) Branch, Islamic Azad University, Isfahan, Iran. Emails: Koa.askari@khuisf.ac.ir, Kaveh.oaa2000@gmail.com

\begin{abstract}
Erg of Gavkhooni Playa is one of the important geomorphologic landforms of Quaternary period in Iran. The area is located on the western part of Gaovkhoni Playa and $140 \mathrm{~km}$ to the Southeast of Isfahan, Iran. This study presents a display of landform of Erg and the area has been divided into three parts (NorthCentral and South). The objective of this study is to identify geomorphologic facieses by GIS $t$ and RS. The research method is a processing technique such as basis analyzing, a composite of panchromatic band with multi-spectral band, to examine line spectral curved, to examine optimum composites using an enhancement method such as filtering and contrast. As a result, to display sand landforms and geomorphologic facieses such as Barkhan, Safe, Star hill, playa's facieses, Skirt and Delta, Sand Zone and the sediment between the hills and geomorphologic landform map are based on Erg of Gavkhoni Playa and geomorphologic facieses of the area.
\end{abstract}

Keywords: Erg Govkhooni Playa, Erg morphology, land sat images, geomorphologic map.

\section{INTRODUCTION}

Ergs are like the largest and dynamic density landforms of the wind erosion system and playa's facieses area. In Iran, in desert areas there are over 40 active wind erosion centers. They are the outcome of the Quaternary climatic dry period and the present time. The area of the desert is over 80 million hectares such that 35 hectares of the area is composed of sand hills and wind erosion landform while 2.5 hectares of the area is located in Esfahan. In Esfahan, wind erosion lands are 1866026 hectares of which 1219420 hectares are affected by wind erosion and 646606 are affected by sediment. Near Isfahan there is an area with the largest wind erosion near Govkhooni Playa. The area is about 265700 hectares of which 240942 hectares is affected by wind erosion and 24758 hectares is affected by sediment. Erg of Govkhooni Playa is the largest wind erosion area in Esfahan city which will be the focus of this study.

A number of researchers who have studied the Erg area are Mahmoodi (1994), Tabatabaee (1995) and Pakzad (2004). In this research, Erg landform has been identified by a remote sensing technique and GIS environment. 
The remote sensing technique and application of land sat images are one of the best techniques to identify and enhance geomorphologic landform in the desert area. The method of this study is the use of land sat images (ETM) to recognize and enhance Erg landform in the western part of Govkhooni Playa. The method involves digital data such as land sat images. On processing the land sat images, involves geometric corrections, examining composite band, using PCA, applying panchromatic (ETM) to composites of multi-spectral and spectral curve. The result of the study was to identify Erg landforms by resolution of geomorphologic facieses and to make a geomorphologic map of Erg which could be used to identify geomorphologic landforms in desert areas.

\section{STUDY AREA}

Gavkhooni Playa is a subside of Negen-Quaterner located 140 kilometer of Esfahan. During the pelioquaternary, the Govkhooni playa was larger than its present form. One study has been identified that pleo realms of Govkhooni playa are in 4 trace.

The continuous climatic Quaternary has controlled the back and forth movement of the realms of playa and the formation system of the area as well as the geomorphologic processing. At present, the time wind erosion function is an important system for formation in the area. Geomorphologic landforms of the area are pediments, alluvial plane, deltas, flood plains and salt area. There are suitable landforms for wind activities. Wind erosion causes forms and wind landform such as Erg which are located in the western part of the Govkhooni Playa. And Govkhooni Playa is a base level and stationing factor for wind activities in the area.

The geographic location of the Erg is 52, 40 to 52, 47 East and 32 to 32, 24 North. The Erg of Ghovkhooni Playa is limited to the south of Zayandeh Rood delta, the western part of Govkhooni playa, North Ezadkhast pediment and East flood plain of Varzneh and Khara.

In this study, land sat (ETM) images with a row of 163-38 on May $27^{\text {th }} 2000$ and ETM spectral band have been used. High quality images are selected in order to identify landform desert and sand dune with a high ability. The images are important to recognize the dimensions of landform and geomorphologic facieses and to enhance the landforms.

In this study, the data formats are based on B.S.Q or continuous band format and all the images converted the band in ER-Mapper environment. ILWIS, ER-Mapper and Arc view were used for processing and analyzing. The vector data are like the topography map on a scale of 1:250000 within Abadeh and Naeen city and the topography map on a scale of 1:50000 of the study area.

Filed work has been done in the study area to make geometric corrections and to check processed images in 5 stages. The image-processing technique will be explained shortly.

\subsection{Examination of Spectral-Curves Bands and Combination of Different Colors}

A profile was made to examine the relationship between the bands and identification of the conduct of spectral curves of sand dune in the study area using the composite colors of spectral curves.

The profile shows different conducts of the spectral of bands in the North, Center and South of the study area. Because of dynamics and density of sand dunes in North of the area compared with the central and southern parts of the Erg area in the central and southern parts are reduced to dense sands, sediments in between the hills and sand zone that affect the conduct of the spectral bands. On the other hand, the conduct of the spectral curves varying from South to North and in some bands completely and some other in similar ways is active. Therefore, when spectral curves overlap, bands have a significant correlation.

Considering the northern part, the conduct of the spectral curve bands of 3,5,6, has a high reflection because they are separate from each other. While, in the center and south of the Erg area there are high reflections in the realm of bands 3,5,6 which are distinct from the spectral curves.

Upon examination of the spectral curves, numerous composite bands such as $653,356,742.321$, and 432,531 have been examined. Among the examining real and false color composites such as 321,742 and 432 are the best composite colors to recognize and identify the Ergs area.

\subsection{Integration of Bands}

In order to increase the resolution of spatial multi-spectral bands to 15 meters, integration or fusion of panchromatic bands has been done. On the other hand, integration, combination, and composition of spatial information 8 bands of images with multi-spectral images of ETM bands were prepared. 
Composite color 472,432 and 321 were used to recover the spatial resolution of multi-spectral bands to reach $15 \mathrm{~m}$. This operation has been completed on ER-Mapper using a BROVY algorithm.

A line-contrast moderate histogram method and spatial filtering put-up gradient type or sharpen- 12 were used. Using this method, it was made possible to identify the different landforms of the North, Center, South and sand dunes of certain sections of the Erg in Govkhooni playa (fig.4, 5)

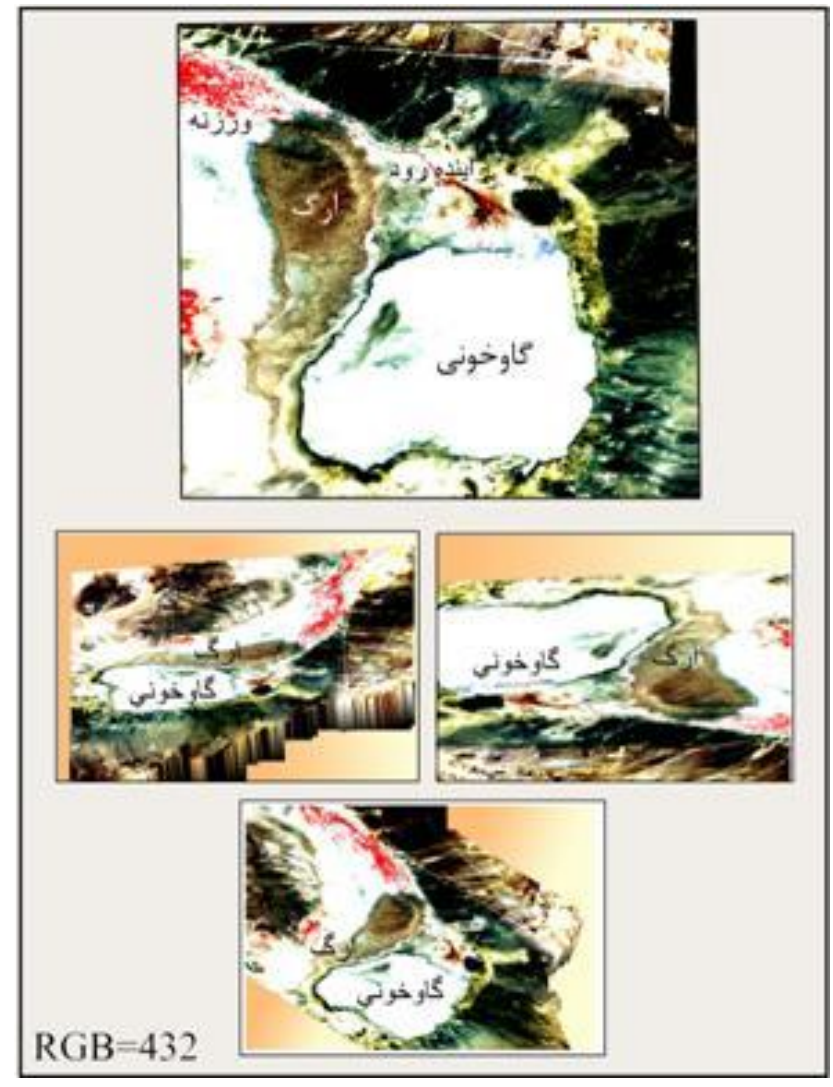

Figure1. Shows Spatial Vew of Govkhooni Erg by Combing 4, 3, 2 Band

\subsection{Analyzing Main Components (PCA)}

In this study, the aim of using PCA technique was to reduce the dimension of the multi-band data to two or three main components. Using this method, it was made possible to identify more geomorphologic facieses. In fact, it could be type of convert for compression of information.

Incidentally, first the base component (PCA 1) and composite main components (PCA 123) were used to operating the bands and extract the main components in order to distinguish landforms and Erg facieses.

\subsection{Mapping DEM (Digital Elevation Model)}

In order to use this method, a topographical map with 1:50000 scale was converted to digital data processing, mosaic and then converted to vector which was completed and then the internal method Digital Elevation Model map was made. The aim of this process was only to display the realm study area with a composite of 4, 3, 2 bands using overlaid Digital Elevation Model.

\subsection{GIS Operation}

GIS software was used in order to make geometric corrections to the sat light images prepared by Digital Elevation Model, measuring the area, length and width of the Erg area and mapping the geomorphologic map.

\subsection{Preparation of Different Composite Bands}

The images were cleared and contrast by examining the spectral curves and testing different real and false composite bands such as 432, 742, 731 and321 by enhancing the conduct such as filtering and using the contrast line of the images. By this method it would be possible to identify sand facieses and analyze the geomorphologic realm of the Erg. 


\subsection{Analyzing the Geomorphology of Erg Using Composite Different Images}

Processing the images was performed in order to display the landform of the Erg area. Therefore, some images were made with different composites in the form of colorful and single colors as well as black (Fig 5). By using the result from the base component mentioned in the methodology, three images were made by composites of three components in the form of single bands (PCA1) (Fig, 2-36 of third image).

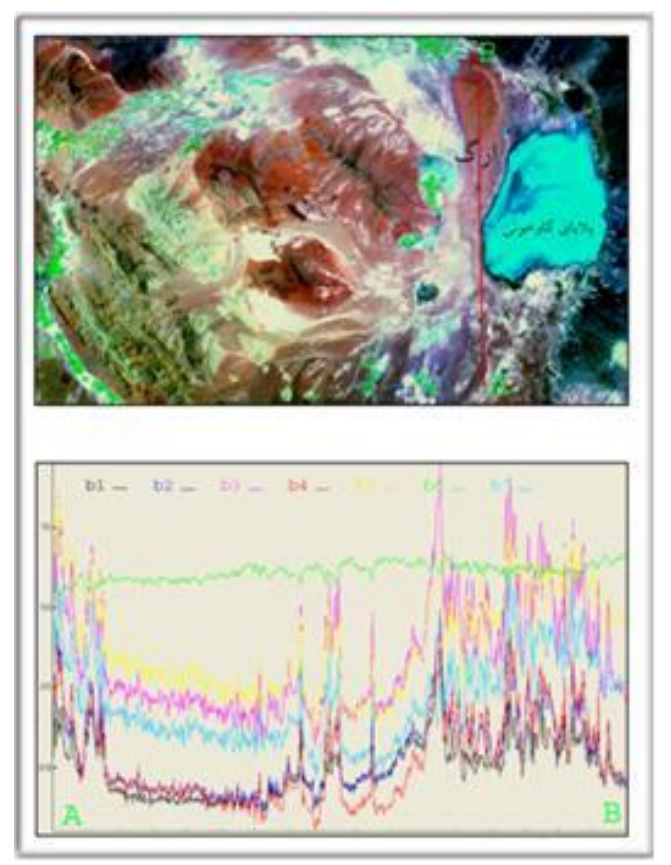

Figure2. Spectral Response Characteristics of Gavkhoni Erg Sand Faces in Different Bands

False color images sere made with 742 and 321 bands in order to make a clearer conduct of the spectral curves in different parts of the Erg area. (Fig, 3)

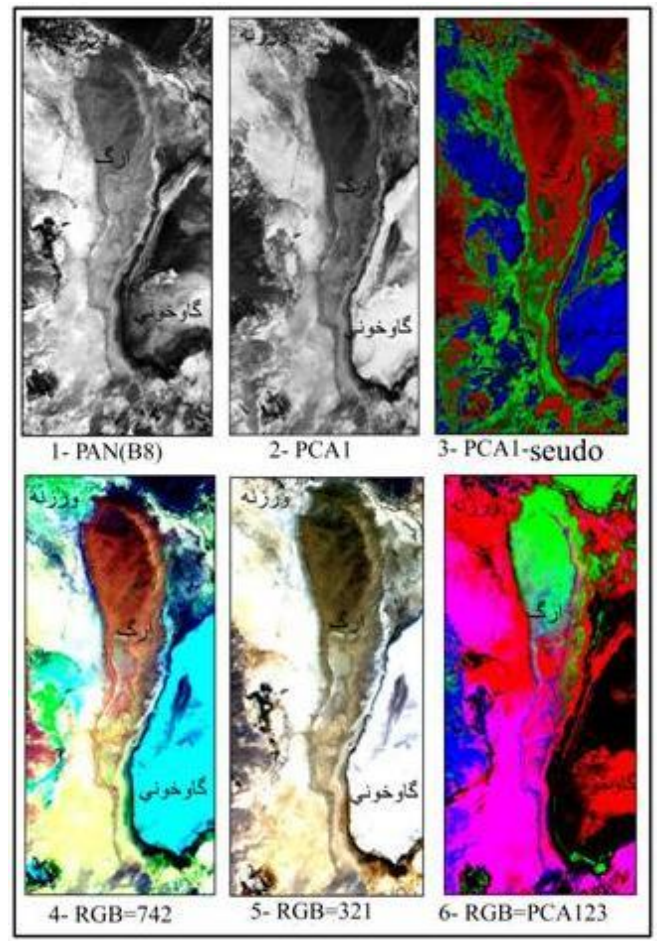

Figure3. Representation of The Outer and Evolution of Gavkhoni Erg by Various Image Processing Techniques.

All of the combination and images had positive responses to display the landform of Erg in the western part of the playa and the whole appearance of the area. In the entire combination images, Erg 
was shown in long form with North-South direction showing the difference of the origin of the sand in the Erg in North and South of the area (RGB=PCA123). On the other hand, the maximum density sands were observable in the Northern part of the area. To make the entire images, enhancement methods involoving filtering and line contrast were used.

\subsection{Analyzing the Landform of Different Parts of the Erg Area by Land Sat Images (ETM)}

In order to enhance the different parts of the Erg area, three combination false colors were used. Figure 4 shows 3 images of the different parts of the area in North-Center and South in different colors and combinations. In this study, such parameters as pattern, shape and color were used for investigation of the images.

According to (Fig 4), the density of the sands was decreased towards North to South. The factors of density for sands in the Erg were a high level of groundwater and humidity of soil, numerous sources of sands such as Zayandeh Rood delta, pediments and alluvial fan in the North, flood plain West of the Erg, wind activities and to carry the sands from Segzi plain and North of Isfahan city. On the other hand, in Northwest of the area, for sand to be removed and the place is a dent because of the dynamics and speed of the moving sand by the Westerly wind North of the Erg area. Fig 4 shows the high density of vegetation by combining the false green color (742) in the North of the Erg area.

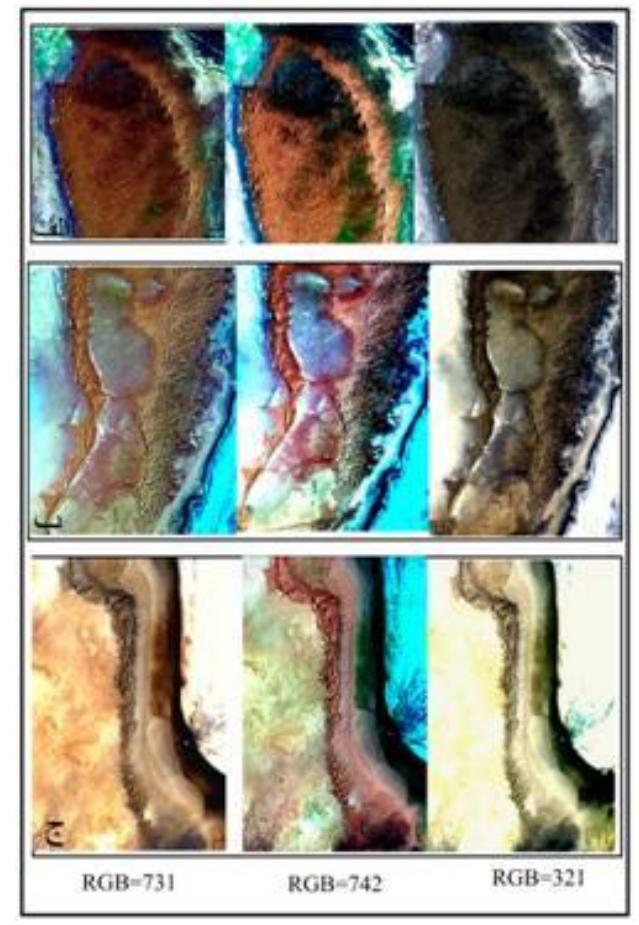

Figure4. Representation of Different Parts of The Gavkhoni Erg in Various Color Band Combinations that have been Obtained by The Integration of Information a)North b) center C) South.

Some parts of the area are artificially covered by human activities in the North and Northwest of the area. In order to protect agricultural lands and human activities in Varzaneh from sand storms and in the internal section of the North part of the Erg area and boundary of the Zayandeh Rood Delta, there are wild vegetations because of the high level under the groundwater and wet soil. During field work, in different parts of the Erg area, it was visible that the boundary of Erg had been moved by climatic change in the quaternary period. Continuous sedimentation of sand in pediment, lakes, profile of Ganat and underground wells in Varzaneh and Hasan Abad state shows the movement of the boundary Erg in the Quaternary period. In Holosen, unlike the present time the sand dune in North of the Erg area has been located in the Western as well as the Southern parts of Varzaneh. Traces of sand dune and civilization of Govkhooni playa under sand dune shows the movement and activities of the Erg area during the Quaternary period.

In the middle part of the Erg area, sand dunes were converted to sedimentation of the hills. Sedimentation of the hills are like geomorphologic facieses involving tiny layers of thick sand made by rainfall and evaporation. This facieses help stabilize the sand which located under the facieses from wind erosion. 
Khara Namak road is located in middle part of the Erg area. Sand broads are located in the Southern part of Erg and sand dunes are in the West and East parts of the area. Sand broad helps stabilize blowing of the sand. Some sand broads are located on the boundary of the playa and Erg, the boundary of Zayandeh Rood Delta, North-West of the Erg, Western and Eastern parts of the Erg. Because there is an exchange of sand between the Erg area and playa Evaporation sediments in the middle section of the playa and boundary of the Erg and playa. This broad of geomorphologic facieses has been shown in fig 7. Below are factors of low density and extent of the sediments in between the hills in the south and middle of the Erg area.

There is the proximity of South area to the mountain, alluvial fan, delta and pediplain of playa. There are no sources of sedimentation. Whereas, in North of the area there are positive sources of sand which such as Zayandeh Rood Delta, clay plain, North pdiplain and flood plain from the western part of the Erg area and Segzi plain in East of Isfahan city which is far from the Erg area. The speed and direction of the wind from the southern to the northern parts of the area there are other factors. On the other hand, the direction of the slope playa from the Northeast to the Southwest causes sand broad of the Eastern part of the Erg with playa composite facieses, puff up facieses and clay salty land in the cold and rainy time of the year and the level of water is high in Govkhooni Playa.

\subsection{Extraction Patterns and Sand Forms in the Realm of the Erg Area Measurement of the Erg Area Using GIS}

The power of spatial resolution is high for controlling the separate spectral spatial images and the size of the sands by enhanced operation. In order to identify the patterns and forms of sands, spatial separating of images (to integrate information of single-band panchromatic ETM+ false- color combination) has reached $15 \mathrm{~m}$. As a result, the forms and hills were identified whose spatial dimensions were higher than those of the integrated images. Then, the sand forms of the Erg area were extracted by enhancement operation, filtering and magnification. Therefore, the sand hills of the Erg Govkhooni playa and the main group such as sand broad, sand hills, Barkhan, Saif hills, long hill sand and star hills has been displayed in four forms (Fig. 5). Most of the sand in the area was displayed in a smaller dimension. The largest hills in the North and central section of the Erg area are in the form of Barkhan and are originated from the wind function blowing from the West. The sand broads are located in most parts of the area. The sand hills are located in center and south of the Erg areas with the largest extensions. Star hills are like the second sediment in the center of the area which have been in existence alongside of the intersecting hills and continuous wind function. In the south and center of the Erg area there is some Barkhan in sight. During field work, all of the forms and processed images are tested.
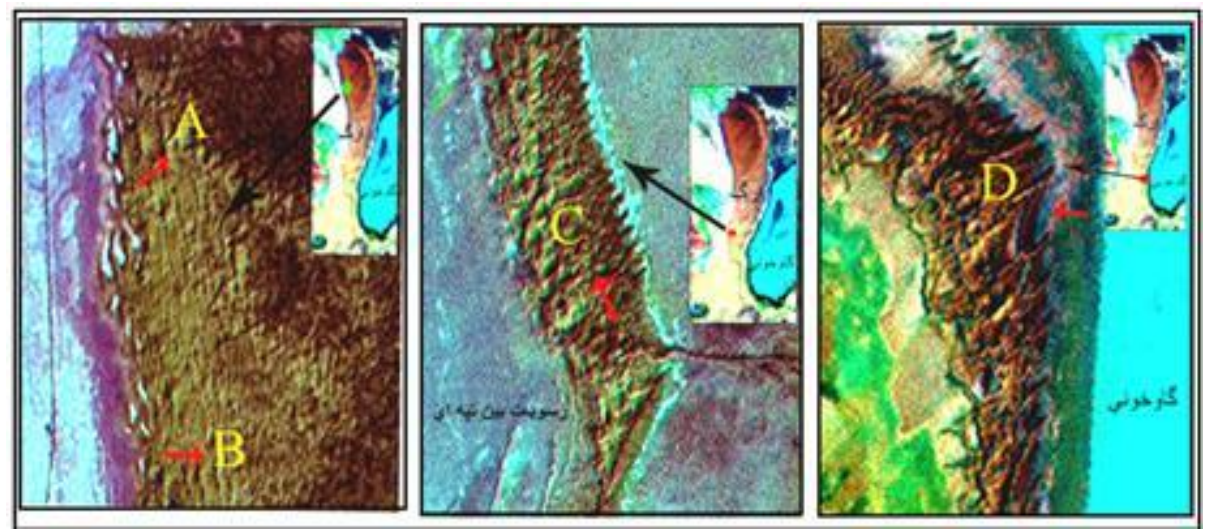

Figure5. Representation of Sand Forms and Forms of Citadel with Information Integration and Image Processing Techniques. A) Dune b)Steep hills C) Hills D) Barkhan.

\subsection{Geomorphologic Mapping of Erg and Govkhooni Playa Area}

Upon processing of the images and combination of the different colors, the study area was checked by field work. The next stage was a combination of color and bands to recognize the landform and geomorphologic facieses of Erg and Govkhooni playa. The combination of colors was 432 and 742. By using magnification operation and putting the processed images as background, the subject layer was extracted from all of the facieses and the sand landform by visual the interpretation method and monitoring of the draw method in the IL WIS software environment and then the layer was converted 
to a vector layer in the GIS environment (Fig 6,7). Once the format was converted to a vector of the images, polygons of the Erg fancies and sand landforms were measured in the Arc view environment. Depending on the operation, the area of the Erg (without sand broad is $145 \mathrm{~km}$ and with sand broad is $180 \mathrm{~km}$ ). The length of the Erg area is $40 \mathrm{~km}$ (with sand broad) and the width is $20 \mathrm{~km}$ in the North and $5 \mathrm{~km}$ in the South.

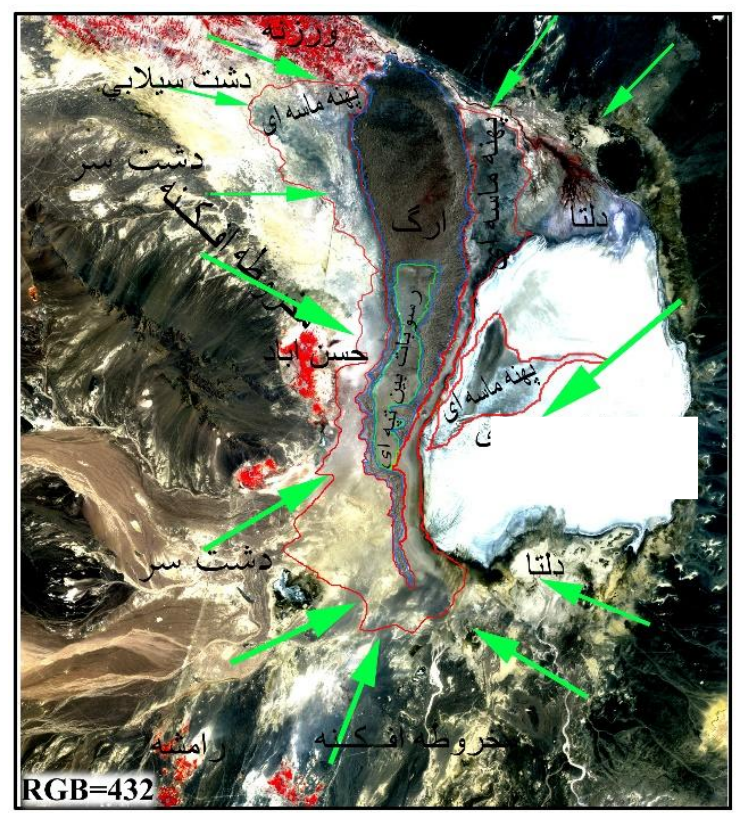

Figure6. Differentiation of Different Facies of Gavkhoni Erg and Its Outlines on the Analyzed Image with False Color Combinations 4,3,2 Bands.

The variety and contrast of the forms and facieses are the results of a variety of geomorphic shortage, river and wind functions.

Therefore, the geomorphologic facieses of the Erg area including the flood and clay plain from Northwest and West, clay and sand broads from the East side (the common boundary of the Erg and Govkhooni playa), sand broads of the West side of the Erg, and salinization of Govkhooni playa in the East side. All of the facieses were tested in the course of field work.

\section{CONCLUSION}

In this study, an important wind density geomorphic form of Govkhooni playa was recognized by processed land sat images (ETM). The sand area is a heritage of the dry climatic Quaternary period of the Eastern part of Isfahan. The remote sensing technique plays an important role in the study of the Ergs and in the identification of the boundary and realm of the Erg area. Such parameters as arrangement of the Erg, dimensions and forms of the sands and power of the spatial separation of the spectral images affected the efficacy of satellite images for enhancement and recognition of facieses and sand hills forms. The integrated operation of the panchromatic bands with a combination of 742 which is the best false color has a positive response to the separate facieses and Erg landform. To apply the technique of the base spectral (PCA), the combination of images has responded to the landform and sand forms of the Erg area. The Erg of Govkhooni playa is the long Erg with Northsouth direction in the West of Govkhooni playa which because of the high humidity of the underground and volume of the sands decreases from North to South. Based on the analyses made from the land sat images, the Erg area has been divided into three parts: North, Center and South. The sands of the Erg area of the Govkhooni playa are of four forms: Sand broad, sand hills, Barkhan, Star hills and Saif. The geomorphologic map and facieses of Govkhooni playa was drawn for the first time. The Erg area is the largest center for wind erosion in Govkhooni playa with some potential occurrence of such materials as minerals, tourism, near human activities area and dynamic energy. Therefore, it is essential to focus more attention and planning on management.

\section{REFERENCES}

[1] Ostad-Ali-Askari, K., Shayannejad, M. 2015, Study of sensitivity of Autumnal wheat to under irrigation in Shahrekord, Shahrekord City, Iran. International Journal of Agriculture and Crop Sciences, 8 (4), $602-605$. 
[2] Shayannejad, M., Akbari, N., Ostad-Ali-Askari, K. 2015, Study of modifications of the river physical specifications on muskingum coefficients, through employment of genetic algorithm. International Journal of Development Research, 5(3), 3782-3785.

[3] Ostad-Ali-Askari, K., Shayannejad, M. 2015, The Reviews of Einstein's Equation of Logarithmic Distribution Platform and the Process of Changes in the Speed Range of the Karkheh River, Khuzestan province, Iran. International Journal of Development Research, 5(3), 3786-3790.

[4] Ostad-Ali-Askari, K., Shayannejad, M., Ghorbanizadee-Kharazi, H. 2015, Assessment of artificial neural network performance and exponential regression in prediction of effective rainfall, International Journal of Development Research, 5(3),3791-3794.

[5] Shayannejad, M. Akbari, N. and Ostad-Ali-Askari, K. 2015, Determination of the nonlinear Muskingum model coefficients using genetic algorithm and numerical solution of the continuity. Int. J. of Science: Basic and Applied Research, 21(1),1-14.

[6] Ostad-Ali-Askari, K., Shayannejad, M. 2015, The Study of Mixture Design for Foam Bitumen and the Polymeric and Oil Materials Function in Loose Soils Consolidation. Journal of Civil Engineering Research, 5(2), 39-44. DOI: 10.5923/j.jce.20150502.04

[7] Sayedipour, M., Ostad-Ali-Askari, K., Shayannejad, M. 2015, Recovery of Run off of the Sewage Refinery, a Factor for Balancing the Isfahan-Borkhar Plain Water Table in Drought Crisis Situation in Isfahan Province-Iran. American Journal of Environmental Engineering, 5(2): 43-46. DOI: 10.5923/j.ajee.20150502.02

[8] Ostad-Ali-Askari, K., Shayannejad, M. 2015, Developing an Optimal Design Model of Furrow Irrigation Based on the Minimum Cost and Maximum Irrigation Efficiency. International Bulletin of Water Resources \& Development, 3(2), 18-23.

[9] Ostad-Ali-Askari, K., Shayannejad, M. 2015, Presenting a Mathematical Model for Estimating the Deep Percolation Due to Irrigation. International Journal of Hydraulic Engineering, 4(1), 17-21. DOI: 10.5923/j.ijhe.20150401.03.

[10] Ostad-Ali-Askari, K., Shayannejad, M. 2015, Usage of rockfill dams in the HEC-RAS software for the purpose of controlling floods. American Journal of Fluid Dynamics, 5(1), 23-29. DOI: 10.5923/j.ajfd.20150501.03.

[11] Ostad-Ali- Askari, K., Shayannejad, M. 2015, The effect of heterogeneity due to inappropriate tillage on water advance and recession in furrow irrigation. Journal of Agricultural Science, 7(6), 127-136.

[12] Shayannejad, M., Ostad-Ali-Askari, K. 2015, Effects of magnetized municipal effluent on some chemical properties of soil in furrow irrigation. International Journal of Agriculture and Crop Sciences, 8(3), 482489.

[13] Ostad-Ali-Askari, K., Shayannejad, M. 2015, Optimal design of pressurized irrigation laterals installed on sloping land. International Journal of Agriculture and Crop Sciences, ISSN 2227-670X. 8(5), 792-797.

[14] Ostad-Ali-Askari K, Shayannejad M, Eslamian S, Navab-Pour B. 2016, Comparison of solution of SaintVenant equations by characteristics and finite difference methods for unsteady flow analyzing in open channel. International Journal of Hydrology Science and Technology, 6(3), 9-18.

[15] Ostad-Ali-Askari K, Shayannejad M, Eslamian S, et al. 2017, Deficit Irrigation: Optimization Models. Management of Drought and Water Scarcity. Handbook of Drought and Water Scarcity, Taylor \& Francis Publisher, USA. Vol. 3. $1^{\text {th }}$ Edition, pp: 373-389.

[16] Eskandari S, Hoodaji M, Tahmourespour A, Abdollahi A, Mohammadian-Baghi T, Eslamian S, Ostad-AliAskari K. 2017, Bioremediation of Polycyclic Aromatic Hydrocarbons by Bacillus Licheniformis ATHE9 and Bacillus Mojavensis ATHE13 as Newly Strains Isolated from Oil-Contaminated Soil. Journal of Geography, Environment and Earth Science International, 11(2): 1-11.

[17] Shayannejad M, Ostad-Ali-Askari K, Eslamian S, et al. 2017, Development of a new method for determination of infiltration coefficients in furrow irrigation with natural non-uniformity of slope. Sustain. Water Resour. Manag., 3(2): 163-169.

[18] Shojaei N, Shafaei-Bejestan M, Eslamian S, Marani-Barzani M, P. Singh V, Kazemi M, Ostad-Ali-Askari K. 2017, Assessment of Drainage Slope on the Manning Coarseness Coefficient in Mountain Area. International Journal of Constructive Research in Civil Engineering (IJCRCE), 3(1): 33-40.

[19] Bahmanpour H, Awhadi S, Enjili J, Eslamian S, Ostad-Ali-Askari K. 2017, Optimizing Absorbent Bentonite and Evaluation of Contaminants Removal from Petrochemical Industries Wastewater. International Journal of Constructive Research in Civil Engineering (IJCRCE), 3(2): 34-42.

[20] Shayannejad M, Eslamian S, Gandomkar A, Marani-Barzani M, Amoushahi-Khouzani M, Majidifar Z, Rajaei-Rizi F, Kazemi M, P. Singh V, Dehghan SH, Shirvani-Dastgerdi H.R, Norouzi H, Ostad-Ali-Askari K. 2017, A Proper Way to Install Trapezoidal Flumes for Measurements in Furrow Irrigation Systems. International Journal of Research Studies in Agricultural Sciences (IJRSAS), 3(7): 1-5. 
[21] Dehghan Sh, Kamaneh S.A.A., Eslamian S, Gandomkar A, Marani-Barzani M, Amoushahi-Khouzani M, Singh V.P., Ostad-Ali-Askari K. 2017, Changes in Temperature and Precipitation with the Analysis of Geomorphic Basin Chaos in Shiraz, Iran. International Journal of Constructive Research in Civil Engineering (IJCRCE), 3(2): 50-57.

[22] Eslamian S, Mirabbasi-Najafabadi R, Ostad-Ali-Askari K. Advance Engineering Statistics (Simulation and Modeling of Uncertainty and Sensitivity Analysis). Kankash Publisher. First Edition, 2017. ISBN: 978600-136-359-7. Isfahan, Iran.

[23] Ostad-Ali-Askari K, Shayannejad M. 2016, FLOOD ROUTING IN RIVERS BY MUSKINGUM'S METHOD WITH NEW ADJUSTED COEFFICIENTS. International Water Technology Journal, IWTJ, 6(3): 189-194.

[24] Ostad-Ali-Askari K, Eslamian S, Shayannejad M, et al. Groundwater Hydrodynamic. Horou fchin Publisher. First Edition, 2016. ISBN: 978-600-7419-53-3. Isfahan, Iran.

[25] Ostad-Ali-Askari K, Shayannejad M, Ghorbanizadeh-Kharazi H. 2017, Artificial Neural Network for Modeling Nitrate Pollution of Groundwater in Marginal Area of Zayandeh-rood River, Isfahan, Iran. KSCE Journal of Civil Engineering, 21(1):134-140. Korean Society of Civil Engineers. DOI 10.1007/ s1 2205-016-0572-8.

[26] Shayannejad M, Ostad-Ali-Askari K, Ramesh A, Singh V.P., Eslamian S. 2017, Wastewater and Magnetized Wastewater Effects on Soil Erosion in Furrow Irrigation. International Journal of Research Studies in Agricultural Sciences (IJRSAS), 3(8): 1-14. http://dx.doi.org/10.20431/2454-6224.0308001.

[27] Shayannejad M, Soltani-Toudeshki A.R, Arab M.A, Eslamian S, Amoushahi-Khouzani M, MaraniBarzani M, Ostad-Ali-Askari K. 2017, A Simple Method for Land Grading Computations and its Comparison with Genetic Algorithm (GA) Method. International Journal of Research Studies in Agricultural Sciences (IJRSAS), 3(8): 26-38.

[28] Mohieyimen P, Eslamian S, Ostad-Ali-Askari K, Soltani M. 2017, Climate Variability: Integration of Renewable Energy into Present and Future Energy Systems in Designing Residential Buildings. International journal of Rural Development, Environment and Health Research(IJREH), 1(2): 18-30.

[29] Shayannejad M, Ostad-Ali-Askari K, Eslamian S, et al. 2017, Flow Hydraulic Investigation of the Wastewater on the Soil and Magnetic Field Effects in This Field. International Journal of Constructive Research in Civil Engineering (IJCRCE), 3(3): 1-15.

[30] Shayannejad M, Eslamian S, Singh V.P., Ostad-Ali-Askari K, et al. 2017, Evaluation of Groundwater Quality for Industrial Using GIS in Mountainous Region of Isfahan Province, Koh-Payeh, Isfahan, Iran. International Journal of Constructive Research in Civil Engineering (IJCRCE), 3(3): 24-37.

[31] Eslamian S, P. Singh V, Ostad-Ali-Askari K, R. Dalezios N, Yihdego Y, et al. 2017, Assessment of Aridity Using Geographical Information System in Zayandeh-Roud Basin, Isfahan, Iran. International Journal of Mining Science (IJMS), 3(2): 49-61.

[32] Askari Z, Samadi-Boroujeni H, Fattahi-Nafchi R, Yousefi N, Eslamian S, Ostad-Ali-Askari K, P. Singh V, R. Dalezios N. 2017, Prediction Comparison of Flow Resistance in Channels with Rounded and Angular Coarse Rough Beds. American Research Journal of Civil And Structural, 3(1): 1-15.

[33] Ghane M, Alvankar S.R., Eslamian S, Amoushahi-Khouzani M, Gandomkar A, Zamani E, Marani-Barzani M, Kazemi M, Soltani M, Dehghan SH, P. Singh V, Ostad-Ali-Askari K, HaeriHamedani M, ShirvaniDastgerdi H.R., Zalaki-Badil N. 2017, Sensitivity Analysis of Runoff Model by SWAT to Meteorological Parameters: A Case Study of Kasillian Watershed, Mazandaran, Iran. International Journal of Research Studies in Agricultural Sciences (IJRSAS), 3(10): 1-20.

[34] Shayannejad M, Abedi M.S., Eslamian S, Ostad-Ali Askari K, Gandomkar A, Cheng A, et al. 2017, The Contribution of Artificial Charging in Optimal Exploitation of Water Resources, Isfahan, Iran. InternationalJournal of Mining Science (IJMS), 3(3): 9-20.

[35] Eslamian S, Ostad-Ali Askari K, et al. 2017, Guidelines to Optimal Design of Furrow Irrigation Based on Plants, Soil and Furrow Specifications. International Journal of Constructive Research in Civil Engineering (IJCRCE), 3(4): 20-39.

[36] Galoie, M., Eslamian, S., and A. Motamedi, 2014, An Investigation of the Influence of a Retention Dam on Flood Control In a Small Catchment Area in Austria, Journal of Flood Engineering, Vol. 5, No. 1/2, 115 .

[37] Hadizadeh, R., Eslamian, S. and Chinipardaz, R., 2013, Investigation of long-memory properties in streamflow time series in Gamasiab River, Iran', Int. J. Hydrology Science and Technology, Vol. 3, No. 4, 319-350.

[38] Amiri, M. J. and S. S. Eslamian, 2010, Investigation of climate change in Iran, Journal of Environmental Science and Technology, Vol. 3, No. 4, 208-216. 
[39] Eslamian, S. S., M. Naderi-beni, M. M. Kohansal, S. Pouriamehr, and A. Nasri, 2014, Investigation of temperature and precipitation changes in Isfahan stations using parametric and nonparametric tests, The 4th International Conference on Environmental Challenges and Dendrochronologoy, Sari, Iran.

[40] Bazrkar, M. H., Zamani, N., Eslamian, S. S., 2014, Investigation of Landuse Impacts on Sediment Yield using a SWAT (Case Study: Chamgodalan Reservoir Watershed, Iran), Proceeding of 3rd ScienceOne International Conference on Environmental Sciences, UAE.

[41] Eslamian, S. S. and S. A. Gohari, 2006, Investigation of Flooding Process in South-Esfahan Basin, International Congress of Islamic World Geographers, Esfahan University, Isfahan.

[42] Eslamian, S. S., Ghoudarzi, A. and R. Nazari, 2006, Investigation of the Changes of Permeability, Physical and Chemical Characteristics of Sediment Basins for Artificial Recharge In Bagh-E-Sorkh Region, Shahreza, Isfahan, 22nd Annual International Conference on Soils, Sediments and Water, University of Massachusetts at Amherst, USA.

[43] Abedi-Koupai, J., Ghaheri, E., Eslamian, S.S. and Hosseini, H., 2013, Investigation the Kinetic Models of Biological Removal of Petroleum Contaminated Soil around Oil Pipeline Using Ryegrass, Water and Wastewater, Vol. 89, No. 1, 62-68.

[44] Ghasemi, A., Eslamian, S. S. and S. M. J. Nazemosadat, 2007, Impact of wind cooling on human comfortability in various regions of Iran, Journal of Research and Investigation of Literature and humanitarian Sciences Faculty, Vol. 24, No. 3, 13-26.

[45] Nasri, M., Najafi, A., Modarres, R. and S. S. Eslamian, 2007, Flood Regional Modelling in south-western Ardestan watershed, Journal of Research and Investigation of Literature and Humanitarian Sciences Faculty, Vol. 27, No. 6, 17-32.

[46] Godarzi, A, S. S. Eslamian and J. Abedi-Koupai, 2004, Investigation of Infiltration changes and physical and chemical characteristics of sediments in Bagh-e-sorkh Shahreza flood spreading strips, Journal of Research in Agricultural Sciences, Vol. 3, No. 1, 33-43.

[47] Nosrati, K., S. S. Eslamian and A. Shahbazi, 2004, Investigation of climate change effect on hydrologic drought, Journal of Agriculture, Vol. 6, No. 1, 49-56.

[48] Yousefi, N., Khodashenas, S. R., Eslamian, S. and Askari, Z. 2016. Estimating width of the stable channels using multivariable mathematical models, Arab. J. Geosci., Vol. 9, No. 321, DOI 10.1007/s12517-016-2322-0.

[49] Banihabib, M. E., Zahraei, A. and Eslamian, S., 2016. Dynamic Programming Model for the System of a Non- Uniform Deficit Irrigation and a Reservoir. Irrigation and Drainage, Vol. 66, No. 1, 71-81

[50] Zalewski, M., McClain, M. and Eslamian, S., 2016. New challenges and dimensions of Ecohydrologyenhancement of catchments sustainability potential, Ecohydrology and Hydrobiology, 16, 1-3

[51] Zalewski, M., McClain, M. and Eslamian, S., 2016. Ecohydrology-the background for the integrative sustainability science, Ecohydrology and Hydrobiology, No. 16, 71-73.

[52] Kouhestani, S., Eslamian, S.S., Abedi-Koupai, J. and Besalatpour, A.A., 2016. Projection of climate change impacts on precipitation using soft-computing techniques: A case study in Zayandeh-rud Basin, Iran. Global and Planetary Change, No. 144, 158-170.

[53] Teimouri, A., Eslamian, S. and Shabankare, A. 2016. Removal of Heavy Metals from Aqueous Solution by Red Alga Gracilaria Corticata as a New Biosorbent, Trends in Life Science, Vol. 5, No. 1, 236-243.

[54] Amiri, M.J., Hamidifar, H., Bahrami, M. and Eslamian, S. (2016) 'Optimisation of deficit-irrigation under variable seasonal rainfall and planning scenarios for rice in a semi-arid region of Iran', International Journal of Hydrology Science and Technology, Vol. 6, No. 4, 331-343.

[55] Salarijazi, M., Abdolhosseini, M., Ghorbani, K. and Eslamian, S. 2016, Evaluation of quasi-maximum likelihood and smearing estimator to improve sediment rating curve estimation', International Journal of Hydrology Science and Technology, Vol. 6, No. 4, 359-370.

[56] Amiri, M.J., Bahrami, M., Hamidifar, H. and Eslamian, S., 2016. Modification of furrow Manning's roughness coefficient estimation by finite difference technique under surge and continuous flow. International Journal of Hydrology Science and Technology, Vol. 6, No. 3, 226-237.

[57] Zahraei, A., Eslamian, S. and Saadati, S., 2016. The effect of water extraction time from the river on the performance of off-stream reservoirs. International Journal of Hydrology Science and Technology, 6(3): 254-265.

[58] Zareian, M. J. and Eslamian, S., 2016, Variation of water resources indices in a changing climate, International Journal of Hydrology Science and Technology, Vol. 6, No. 2, 173 - 187.

[59] Fathian, F., Dehghan, Z.., Eslamian, S., Adamowski, J., 2016, Assessing Irrigation Network Performance Based on Different Climate Change and Water Supply Scenarios: A Case Study in Northern Iran, International Journal of Water, Accepted. 
[60] Fathian, F., Dehghan, Z.., Eslamian, S., 2016, Evaluating the impact of changes in land cover and climate variability on streamflow trends (case study: eastern subbasins of Lake Urmia, Iran), J. Hydrology Science and Technology, Vol. 6, No. 1, 1-26.

[61] Dalezios, N. R. and Eslamian, S, 2016, Regional design storm of Greece within the flood risk management framework, Int. J. Hydrology Science and Technology, Vol. 6, No. 1, 82-102.

[62] Kamali, M. I., Nazari, R., Fridhosseini, A., Ansari, H., Eslamian, S., 2015, The Determination of Reference Evapotranspiration for Spatial Distribution Mapping Using Geostatistics, Vol. 29: 3929-3940.

[63] Talchabhadel , R., Shakya, N. M. Dahal , V., and Eslamian, S., 2015, Rainfall Runoff Modelling for Flood Forecasting (A Case Study on West Rapti Watershed), Journal of Flood Engineering, Vol. 6, No. 1, 53-61.

[64] Yousefi, N., Safaee, A., Eslamian, S., 2015, The Optimum Design of Flood Control System Using Multivariate Decision Making Methods (Case Study: Kan River Catchment Basin, Iran), Journal of Flood Engineering, Vol. 6, No. 1, 63-82.

[65] Banihabib, M. E., Zahraei, A. and Eslamian, S., 2015, An integrated optimization model of reservoir and irrigation system applying uniform deficit irrigation, Int. J. Hydrology Science and Technology, Vol. 5, No. 4, 372-385.

[66] Fathian, F., Prasad, A. D., Dehghan, Z.., Eslamian, S., 2015, Influence of land use/land cover change on land surface temperature using RS and GIS techniques, Int. J. Hydrology Science and Technology, Vol. 5, No. 3, 195-207.

[67] Abedi-koupai, J., Mollaei, R., Eslamian, S. S., 2015, The effect of pumice on reduction of cadmium uptake by spinach irrigated with wastewater, Ecohydrology and Hydrobiology, Vol. 15, No. 4, 208-214.

[68] Kamali, M. I., Nazari, R., Faridhosseini, A., Ansari, H., Eslamian, S., 2015, The Determination of Reference Evapotranspiration for Spatial Distribution Mapping Using Geostatistics, Water Resources Management, 29:3929-3940.

[69] Valipour, M., Gholami Sefidkouhi, M. A., Eslamian, S., 2015, Surface irrigation simulation models: a review, Int. J. Hydrology Science and Technology, Vol. 5, No. 1, 51-70.

[70] Esmailzadeh, M., Heidarpour, M., Eslamian, S. , 2015, Flow characteristics of sharp-crested side sluice gate, ASCE's Journal of Irrigation and Drainage Engineering, Vol. 141, No. 7, 10.1061/(ASCE)IR.19434774.0000852.

[71] Zareian, M. J., Eslamian, S. and Safavi, H. R., 2015, A modified regionalization weighting approach for climate change impact assessment at watershed scale, Theor. Appl. Climatol., 122:497-516.

[72] Boucefiane A., Meddi M., Laborde J. P., Eslamian S. S., 2014, Rainfall Frequency Analysis Using Extreme Values, Distributions In the Steppe Region of Western Algeria, Int. J. Hydrology Science and Technology, Vol. 4, No. 4, 348-367.

[73] Valipour, M., Eslamian, S., 2014, Analysis of potential evapotranspiration using 11 modified temperaturebased models, Int. J. Hydrology Science and Technology, Vol. 4, No. 3, 192-207.

[74] Meddi, M., Toumi, S., Assani, A. A., Eslamian, S., 2014, Regionalization of Rainfall Erosivity in Northern Algeria, Int. J. Hydrology Science and Technology, Vol. 4, No. 2, 155-175.

[75] Zohrabi, N., Massah Bavani, A., Goodarzi, E., S. Eslamian, 2014, Attribution of temperature and precipitation changes to greenhouse gases in northwest Iran, Quaternary International, Vol. 345, 130-137.

[76] Farshad F., Dehghan, Z., Eslamian, S., H. Bazrkar, 2015, Trends in hydrologic and climatic variables affected by four variations of Mann-Kendall approach in Urmia Lake basin, Iran, Hydrological Sciences Journal, DOI:10.1080/02626667.2014.932911.

[77] Fazlolahi, H. and S. S. Eslamian, 2014, Using wetland plants in nutrient removal from municipal wastewater, Int. J. Hydrology Science and Technology, Vol. 4, No. 1, 68-80.

[78] Farshad F., Dehghan, Z. and S. Eslamian, 2014, Analysis of Water Level Changes in Lake Urmia Based on Data Characteristics and Nonparametric Test, Int. J. Hydrology Science and Technology, Vol. 4, No. 1, 18-38.

[79] Varshney, L., Saket, R. K. and Eslamian, S., 2013, Power estimation and reliability evaluation of municipal waste water and self-excited induction generator-based micro hydropower generation system, Int. J. Hydrology Science and Technology, Vol. 3, No. 2, 176-191.

[80] Amiri, M. J., Abedi-Koupai, J., Eslamian, S., Mousavi, S. F. and Arshadi, M., 2013, Modelling Pb(II) adsorption based on synthetic and industrial wastewaters by ostrich bone char using artificial neural network and multivariate non-linear regression, Int. J. Hydrology Science and Technology, Vol. 3, No. 3, 221-240.

[81] Eslamian, S., Tarkesh Esfahany, S., Nasri, M. and Safamehr, M., 2013, Evaluating the potential of urban reclaimed water in area of north Isfahan, Iran, for industrial reuses, Int. J. Hydrology Science and Technology, Vol. 3, No. 3, 257-269. 
[82] Ajigoh, E. and Eslamian, S., 2013, Nyando catchment GIS modeling of flood in undated areas, Journal of Flood Engineering, Vol. 4, No. (1-2), 77-86.

[83] Galoie, M., Zenz, G. and Eslamian, S., 2013, Determining the high flood risk regions using a rainfallrunoff modeling in a small basin in catchment area in Austria, Journal of Flood Engineering, Vol. 4, No. (1-2), 9-27.

[84] Bazrkar, M. H., Fathian, F., and Eslamian, S., 2013, Runoff modeling in order to investigate the most effective factors in flood events using system dynamic approach (Case study: Tehran Watershed, Iran), Journal of Flood Engineering, Vol. 4, No. 1-2, 39-59.

[85] Galoie, M., Zenz, G. and Eslamian, S., 2013, Application of L-moments for IDF determination in an Austrian basin, Int. J. Hydrology Science and Technology, Vol. 3, No. 1, 30-48.

[86] Rostamian, R., Eslamian, S. and Farzaneh, M. R., 2013, Application of standardised precipitation index for predicting meteorological drought intensity in Beheshtabad watershed, central Iran, Int. J. Hydrology Science and Technology, Vol. 3, No. 1, 63-77.

[87] Bahmani, R., Radmanesh, F., Eslamian, S., Khorsandi, M. and Zamani, R., 2013, Proper Rainfall for Peak Flow Estimation by Integration of L-Moment Method and a hydrologic model, International Research Journal of Applied and Basic Sciences, Vol. 4 No. 10, 2959-2967.

[88] Mirabbasi, R., Anagnostou, E. N., Fakheri-Fard, A. Dinpashoh, Y. and Eslamian, S., 2013, Analysis of meteorological drought in northwest Iran using the Joint Deficit Index, Journal of Hydrology, Vol. 492, $35-48$.

[89] Gohari, A., Eslamian, S., Mirchi, A., Abedi-Koupaei, J., Massah-Bavani, A., Madani, K., 2013, Water transfer as a solution to water shortage: A fix that can blackfire, Journal of Hydrology, Vol. 491, 23-39.

[90] Haghiabi, A. H., Mohammadzadeh-Habili, J., Eslamian, S. S., and S. F. Mousavi, 2013, Derivation of Ewservior's Area-Capacity Equations Based on the Shape Factor, Iranian Journal of Science and Technology, Vol. 37, No. C1, 163-167.

[91] Gohari, A., Eslamian, S., Abedi-Koupaei, J., Massah-Bavani, A., Wang, D., Madani, K., 2013, Climate change impacts on crop production in Iran's Zayandeh-Rud River Basin. Science of The Total Environment, Vol. 442, 405-419.

[92] Saatsaz, M., Azmin Sulaiman, W. N., Eslamian, S., Javadi, S., 2013, Development of a coupled flow and solute transport modelling for Astaneh-Kouchesfahan groundwater resources, North of Iran, International Journal of Water, Vol. 7, No.1/2, $80-103$.

[93] Saatsaz, M., Azmin-Sulaiman, W. N., Eslamian, S., Mohammadi, K., 2013, Hydrogeochemistry and groundwater quality assessment of Astaneh-Kouchesfahan Plain, Northern Iran, International Journal of Water, Vol. 7, No. 1/2, $44-65$.

[94] Eslamian, S., Amiri, M. J., Abedi-Koupai, J. and S. Shaeri-Karimi, 2013, Reclamation of unconventional water using nano zero-valent iron particles: an application for groundwater, International Journal of Water, Vol. 7, No. 1/2, 1-13.

[95] Amiri, M.J., Abedi-koupai, J., Eslamian, S. S., Mousavi, S. F., Hasheminejad, H., 2013, Modeling Pb (II) adsorption from aqueous solution by ostrich bone ash using adaptive neural-based fuzzy inference system, J Environ. Sci. Health A Tox. Hazard Subst. Environ. Eng., Vol. 48, No. 5: 543-58.

[96] Biabanaki, M., Tabatabaei Naeini, A. and S. S. Eslamian, 2012, Effects of Urbanization on Stream Channels, Journal of Civil Engineering and Urbanism (JCEU), Vo. 2, No. 4, 136-142.

[97] Abdolhosseini, M., Eslamian, S., Mousavi, S. F., 2012, Effect of climate change on potential evapotranspiration: a case study on Gharehsoo sub-basin, Iran, Vol. 2 No. 4, 362-372.

[98] Farzaneh, M. R., Eslamian, S. S., Samadi, Z. and A. Akbarpour, 2012, An appropriate general circulation model (GCM) to investigate climate change impact, International Journal of Hydrology Science and Technology, Vol. 2, No. 1, 34-47.

[99] Eslamian, S., Abedi-Koupai, J. and M. J. Zareian., 2012, Measurement and modelling of the water requirement of some greenhouse crops with artificial neural networks and genetic algorithm, International Journal of Hydrology Science and Technology, Vol. 2, No. 3, 237-251.

[100]Sadeghi, S. H., Mousavi, S. F., Eslamian, S. S., Ansari, S. and F. Alemi, 2012, A Unified Approach for Computing Pressure Distribution in Multi-Outlet Irrigation Pipelines, Iranian Journal of Science and Technology, Vol. 36, No. C2, 209-223.

[101]Alaghmand, S., Bin Abdullah, R., Abustan, I. and S. Eslamian, 2012, Comparison between capabilities of HEC-RAS and MIKE11 hydraulic models in river flood risk modeling (a case study of Sungai Kayu Ara River basin, Malaysia), International Journal of Environmental Science and Technology, Vol. 2, No. 3, 270-291.

[102]Galoie, M., Zenz, G., S. Eslamian and A. Motamedi., 2012, Numerical simulation of flood due to dambreak flow using an implicit method, International Journal of Environmental Science and Technology, Vol. 2, No. 2, 117-137. 
[103]Ghazavi, R., A. B. Vali and S. Eslamian, 2012, Impact of Flood Spreading on Groundwater Level Variation and Groundwater Quality in an Arid Environment, Water Resource Management, Vol. 26, No. 6, 1651-1663.

[104]Fakhri, M., Farzaneh, M. R., Eslamian, S. and M. J. Khordadi, 2012, Uncertainty Assessment of Downscaled Rainfall: Impact of Climate Change on the Probability of Flood, Journal of Flood Engineering, Vol. 3, No. 1, 19-28.

[105]Gholami. A., Mahdavi, M. and S. Eslamian, 2012, Probability Distribution Choices for Minimum, Mean and Maximum Discharges, by L-Moments in Mazandaran Province, IRAN, Journal of Flood Engineering, Vol. 3, No. 1, 83-92.

[106]Shaeri karimi, S., Yasi, M. and S. S. Eslamian, 2012, Use of Hydrological Methods for Assessment of Environmental Flow in a River Reach, International Journal of Environmental Science and Technology, 9(3), pp 549-558.

[107]Eslamian, S. S., Hassanzadeh, H., Abedi-Koupai, J. and M. Gheysari, 2012, Application of L-moments for Regional Frequency Analysis of Monthly Drought Indices, Journal of Hydrologic Engineering, Vol. 17, No. 1, 32-42.

[108]Farzaneh, M. R., Eslamian, S. S., Samadi, Z. and A. Akbarpour, 2012, An appropriate general circulation model (GCM) to investigate climate change impact, International Journal of Hydrology Science and Technology, Vol. 2, No. 1, 34-47.

[109]Eslamian, S. S., Khordadi, M. J. and J. Abedi-Koupai, 2011, Effects of Variations In Climatic Parameters on Evapotranspiration In the Arid and Semi-Arid Regions, Global and Planetary Change, Vol. 78, 188194.

[110]Eslamian, S. S. and M. J. Amiri, 2011, Estimation of daily pan evaporation using adaptive neural-based fuzzy inference system, International Journal of Hydrology Science and Technology, Vol. 1, Nos. 3/4, 164-175.

[111]Eslamian, S. S., Shaeri Karimi S. and F. Eslamian, 2011, A country case study comparison on Groundwater and Surface Water Interaction, International Journal of Water, Vol. 6, Nos. 1/2, 117-136.

[112]Eslamian, S. S., Gohari, A., Zareian M. J. and A. Firoozfar, 2012, Estimating Penman-Monteith Reference Evapotranspiration Using Artificial Neural Networks and Genetic Algorithm: A Case Study, The Arabian Journal for Science and Engineering, Vol. 37, No. 4, 935-944.

[113]Hassanzadeh, H., Eslamian, S. S., Abedi-Koupai, J. and M. Gheysari, 2011, Application of L-moment for evaluating drought indices of cumulative precipitation deficit (CPD) and maximum precipitation deficit (MPD) based on regional frequency analysis, International Journal of Hydrology Science and Technology, Vol. 1, Nos. 1/2, 88-104.

[114]Alipour, M. H., Shamsai, A., Eslamian, S. S. and R. Ghasemizadeh, 2011, A new fuzzy technique to find the optimal solution in flood management, Journal of Flood Engineering, Vol. 2, No. 1, 1-9.

[115]Ghasemizade, M., Mohammadi K., and S. S. Eslamian, 2011, Estimation of design flood hydrograph for an ungauged watershed, Journal of Flood Engineering, Vol. 2, No. 1/2, $27-36$.

[116]Dhital, Y. P., Kayastha, R. B. and S. S. Eslamian, 2011, Precipitation and discharge pattern analysis: a case study of Bagmati River basin, Nepal, Journal of Flood Engineering, Vol. 2, No. 1, 49-60.

[117]Saatsaz, M., Sulaiman, W.N.A. and S. S. Eslamian, 2011, GIS DRASTIC model for groundwater vulnerability estimation of Astaneh-Kouchesfahan Plain, Northern Iran, International Journal of Water, Vol. 6, No. 1/2, 1-14.

[118]Saatsaz, M., Chitsazan, M., Eslamian, S. S. and W.N.A. Sulaiman, 2011, The application of groundwater modelling to simulate the behaviour of groundwater resources in the Ramhormooz Aquifer, Iran, International Journal of Water, Vol. 6, Nos. 1/2, 29-42.

[119]Kambona, O. O., Stadel, C. and S. S. Eslamian, 2011, Perceptions of tourists on trial use and management implications for Kakamega Forest, Western Kenya, Journal of Geography and Regional Planning Vol. 4, No. 4, 243-250.

[120]Malekian, R., Abedi-Koupai, J., Eslamian, S. S., Mousavi, S. F., Abbaspour, K. C. and M. Afyuni, 2011, Ion-exchange process for ammonium removal and release using natural Iranian zeolite, Applied Clay Science, Vol. 51, 323-329.

[121]Malekian, R., Abedi-Koupai, J. and S. S. Eslamian, 2011, Influences of clinoptilolite and surfactantmodified clinoptilolite zeolite on nitrate leaching and plant growth, Journal of Hazardous Materials, Vol. 185, 970-976.

[122]Malekian, R., Abedi-Koupai, J. and S. S. Eslamian, 2011, Use of Zeolite and Surfactant Modified Zeolite as Ion Exchangers to Control Nitrate Leaching, World Academy of Science, Engineering and Technology, Vol. 76, 657-661. 
[123]Zaky, M. M. M., Salem, M. A. M., Persson, K. M. M. and S. S. Eslamian, 2011, Incidence of Aeromonas species isolated from water and fish sources of Lake Manzala in Egypt, International Journal of Hydrology Science and Technology, Vol. 1, Nos. 1/2, 47-62.

[124]Khorsandi, Z., Mahdavi, M., Salajeghe, A. and S. S. Eslamian, 2011, Neural Network Application for Monthly Precipitation Data Reconstruction, Journal of Environmental Hydrology, Vol. 19, Paper 5, 1-12.

[125]Eslamian, S. S., 2010, The Physically-Statistically Based Region of Influence Approach for Flood Regionalization, Journal of Flood Engineering, Vol. 1, No. 2, 149-158.

[126]Eslamian, S. S., 2010, Flood Regionalization Using a Modified Region of Influence Approach, Journal of Flood Engineering, Vol. 1, No. 1, 51-66.

[127]Eslamian, S. S., Ghasemizadeh, M., Biabanaki, M. and M. Talebizadeh, 2010, A principal component regression method for estimating low flow index, Water Resources Management, Vol. 24, No. 11, 25532566.

[128]Ghazavi, R., Vali, A. B. and S. S. Eslamian, 2010, Impact of flood spreading on infiltration rate and soil properties in an arid environment, Water Resources Management, Vol. 24, No. 11, 2781-2793.

[129]Rajabi, A., Sedghi, H., Eslamian, S. S. and H. Musavi, 2010, Comparison of Lars-WG and SDSM downscaling models in Kermanshah (Iran), Ecol. Env. \& Cons., Vol. 16, No. 4, 1-7.

[130]Rahnamai Zekavat, P., Ghasemizadeh, R., Eslamian, S. S. and S. Tarkesh Isfahani, 2010, Journal of Flood Engineering, Vol. 1, No. 2, 175-184.

[131]Chavoshi Borujeni, S., Sulaiman, W. N. A. and S. S. Eslamian, 2010, Regional Flood Frequency Analysis Using L-Moments for North Karoon Basin Iran, Journal of Flood Engineering, Vol. 1, No. 1, 67-76.

[132]Kloub, N., Matouq, M., Krishan, M., Eslamian, S. S. and M. Abdelhadi, 2010, Monitoring of Water Resources Degradation at Al-Azraq Oasis, Jordan Using Remote Sensing and GIS Techniques, International Journal of Global Warming, Vol. 2, No. 1, 1-16.

[133] Akhavan S., Abedi-Koupai, J, Mousavi, S, F., Afyuni, M., Eslamian, S. S. and K. C. Abbaspour, 2010, Application of SWAT model to investigate nitrate leaching in Hamadan-Bahar Watershed, Iran, Agriculture, Ecosystems and Environment, Vol. 139, 675-688.

[134]Eslamian, S. S., Abedi-Koupai, J., Amiri, M, J., and A. R. Gohari, 2009, Estimation of Daily Reference Evapotranspiration Using Support Vector Machines and Artificial Neural Networks in Greenhouse, Research Journal of Environmental Sciences, Vol. 3, No. 4, 439-447.

[135]Eslamian, S. S. and N. Lavaei, 2009, Modelling Nitrate Pollution of Groundwater using Artificial Neural Network and Genetic Algorithm in an Arid Zone, International Journal of Water, Special Issue on Groundwater and Surface Water Interaction (GSWI), Vol. 5, No. 2, 194-203.

[136]Eslamian, S. S. and M. J. Khordadi, 2009, Comparing Rainfall and Discharge Trends in Karkhe Basin, Iran, International Journal of Ecological Economics \& Statistics (IJEES), Vol. 15, No. F09, 114-122.

[137]Eslamian, S. S. and B. Nekoueineghad, 2009, A Review on Interaction of Groundwater and Surface Water, International Journal of Water, Special Issue on Groundwater and Surface Water Interaction (GSWI), Vol. 5, No. 2, 82-99.

[138]Eslamian, S. S. and N. Zamani, 2009, Innovations in Wind Modelling, International Journal of Global Energy Issues, Special Issue on Wind Modelling and Frequency Analysis (WMFA), Vol. 32, No. 3, 175 190.

[139]Eslamian, S. S. and H. Hasanzadeh, 2009, Detecting and Evaluating Climate Change Effect on Frequency Analysis of Wind Speed in Iran, International Journal of Global Energy Issues, Special Issue on Wind Modelling and Frequency Analysis (WMFA). Vol. 32, No. 3, 295 - 304.

[140]Eslamian, S. S., 2009, Editorial: Frontiers in Ecology and Environment, International Journal of Ecological Economic \& Statistics, Special Issue on Basin Ecology and Environment (BEE), Vol. 13, No. W09, 1-6.

[141]Eslamian, S. S. and M. Biabanaki, 2009, Low Flow Regionalization Models, International Journal of Ecological Economic \& Statistics, Special Issue on Stream Ecology and Low Flows (SELF), Vol. 12, No. F08, 82-97.

[142]Eslamian, S. S., 2009, Editorial: An Ecologically Based Low Flow Review, International Journal of Ecological Economic \& Statistics, Special Issue on Stream Ecology and Low Flows (SELF), Vol. 12, No. F08, 1-6.

[143]Nosrati, K., Eslamian, S. S., Shahbazi, A., Malekian, A. and M. M. Saravi, 2009, Application of Daily Water Resources Assessment Model for Monitoring Water Resources Indices, International Journal of Ecological Economic \& Statistics, Special Issue on Basin Ecology and Environment (BEE), Vol. 13, No. W09, 88-99.

[144]Abedi-Koupai, J., Amiri, M. J., and S. S. Eslamian, 2009, Comparison of Artificial Neural Network and Physically Based Models for Estimating of Reference Evapotranspiration in Greenhouse, Australian Journal of Basic and Applied Sciences, Vol. 3, No. 3, 2528-2535, 
[145]Ebrahimizadeh, M. A., Amiri, M. J., Eslamian, S. S., Abedi-Koupai, J. and M. Khozaei, 2009, The Effects of Different Water Qualities and Irrigation Methods on Soil Chemical Properties, Research Journal of Environmental Sciences, Vol. 3, No. 4, 497-503.

[146]Matouq, M., Amarneh, I. A., Kloub, N., Badran, O., Al-Duheisat, S. A. and S. S. Eslamian, 2009, Investigating the Effect of Combustion of Blending Jordanian Diesel Oil with Kerosene on Reducing the Environmental Impacts by Diesel Engine, International Journal of Ecological Economic \& Statistics, Special Issue on Basin Ecology and Environment (BEE), Vol. 13, No. W09, 79-87.

[147]Eslamian S. S., Gohari, A., Biabanaki, M. and R. Malekian, 2008, Estimation of Monthly Pan Evaporation Using Artificial Neural Networks and Support Vector Machines, Journal of Applied Sciences, Vol. 7, No. 19, 2900-2903.

[148]Abedi-Koupai J., Eslamian S. S. and J. Asad Kazemi, 2008, Enhancing the available Water Content in Unsaturated Soil Zone using Hydrogel, to Improve Plant Growth Indices, Ecohydrology and Hydrobiology, Vol. 8, No. 1, 3-11.

[149]Bazgeer, S., Kamali, G. A., Eslamian, S. S., Sedaghatkerdar, A. and I. Moradi, 2008, Pre-Harvest Wheat Yield Prediction Using Agrometeorological Indices for Different Regions of Kordestan Province, Iran, Research Journal of Environmental Sciences, Vol. 2, No. 4, 275-280.

[150]Eslamian, S. S. and H. Feizi, 2007, Maximum Monthly Rainfall Analysis Using L-moments for an Arid Region in Isfahan Province, Iran, Journal of Applied Meteorology and Climatology, Vol. 46, No. 4, 494503.

[151]Modarres, R., Soltani, S. and S. S. Eslamian, 2007, The Use of Time Series Modeling for the Determination of Rainfall Climates of Iran, International Journal of Climatology, Vol. 27, No. 6, 819829.

[152]Moradi, I., Nosrati, K. and S. S. Eslamian, 2007, Evaluation of the RadEst and ClimGen Stochastic Weather Generators for Low-Medium Rainfall Regions, Journal of Applied Sciences, Vol. 7, No. 19, 2900-2903.

[153]Modarres R. and S. S. Eslamian, 2006, Streamflow Time Series Modeling of Zayandehrud River, Iranian Journal of Science and Technology, Vol. 30, No. B4, 567-570.

[154]Mostafazadeh-fard, B., Osroosh, Y. and S. S. Eslamian, 2006, Development and Evaluation of an Automatic Surge Flow Irrigation System, Journal of Agriculture and Social Sciences, Vol. 2, No. 3, 129132.

[155]Coles, N. A. and Eslamian, S., 2017, Definition of Drought, Ch. 1 in Handbook of Drought and Water Scarcity, Vol. 1: Principles of Drought and Water Scarcity, Ed. by Eslamian S. and Eslamian F., Francis and Taylor, CRC Press, USA, 1-12.

[156]Dalezios, N. R., Dunkel, Z., Eslamian, S., 2017, Meteorological Drought Indices: Definitions, Ch. 3 in Handbook of Drought and Water Scarcity, Vol. 1: Principles of Drought and Water Scarcity, Ed. by Eslamian S. and Eslamian F., Francis and Taylor, CRC Press, USA, 24-44.

[157]Goyal, M. K. Gupta, V., Eslamian, S., 2017, Hydrological Drought: Water Surface and Duration Curve Indices, Ch. 4 in Handbook of Drought and Water Scarcity, Vol. 1: Principles of Drought and Water Scarcity, Ed. by Eslamian S. and Eslamian F., Francis and Taylor, CRC Press, USA, 45-72.

[158]Dalezios, N. R., Gobin, A., Tarquis Alfonso, A. M., and Eslamian, S., 2017, Agricultural Drought Indices: Combining Crop, Climate, and Soil Factors, Ch. 5 in Handbook of Drought and Water Scarcity, Vol. 1: Principles of Drought and Water Scarcity, Ed. by Eslamian S. and Eslamian F., Francis and Taylor, CRC Press, USA, 73-90.

[159]TishehZan, P. and Eslamian, S., 2017, Agricultural Drought: Organizational Perspectives, Ch. 6 in Handbook of Drought and Water Scarcity, Vol. 1: Principles of Drought and Water Scarcity, Ed. by Eslamian S. and Eslamian F., Francis and Taylor, CRC Press, USA, 91-108.

[160]Bazrkar, M. H., Eslamian, S., 2017, Ocean Oscillation and Drought Indices: Application, Ch. 8 in Handbook of Drought and Water Scarcity, Vol. 1: Principles of Drought and Water Scarcity, Ed. by Eslamian S. and Eslamian F., Francis and Taylor, CRC Press, USA, 127-136.

[161]Basu, R., Singh, C. K., Eslamian, S., 2017, Cause and Occurrence of Drought, Ch. 9 in Handbook of Drought and Water Scarcity, Vol. 1: Principles of Drought and Water Scarcity, Ed. by Eslamian S. and Eslamian F., Francis and Taylor, CRC Press, USA, 137-148.

[162]Bazrafshan, J., Hejabi, S., Eslamian, S., 2017, Drought Modeling Examples, Ch. 11 in Handbook of Drought and Water Scarcity, Vol. 1: Principles of Drought and Water Scarcity, Ed. by Eslamian S. and Eslamian F., Francis and Taylor, CRC Press, USA, 167-188.

[163]Jonathan Peter Cox, Sara Shaeri Karimi, Eslamian, S., 2017, Real-Time Drought Management, Ch. 13 in Handbook of Drought and Water Scarcity, Vol. 1: Principles of Drought and Water Scarcity, Ed. by Eslamian S. and Eslamian F., Francis and Taylor, CRC Press, USA, 209-216. 
[164]Garg, V. and Eslamian, S., 2017, Monitoring, Assessment, and Forecasting of Drought Using Remote Sensing and the Geographical Information System. Ch. 14 in Handbook of Drought and Water Scarcity, Vol. 1: Principles of Drought and Water Scarcity, Ed. by Eslamian S. and Eslamian F., Francis and Taylor, CRC Press, USA, 217-252.

[165]Dalezios, N. R., Tarquis Alfonso, A. M., and Eslamian, S., 2017, Drought Assessment and Risk Analysis, Ch. 18 in Handbook of Drought and Water Scarcity, Vol. 1: Principles of Drought and Water Scarcity, Ed. by Eslamian S. and Eslamian F., Francis and Taylor, CRC Press, USA, 323-344.

[166]Dalezios, N. R., Spyropoulosand, N. V., Eslamian, S., 2017, Remote Sensing in Drought Quantification and Assessment, Ch. 21 in Handbook of Drought and Water Scarcity, Vol. 1: Principles of Drought and Water Scarcity, Ed. by Eslamian S. and Eslamian F., Francis and Taylor, CRC Press, USA, 377-396.

[167]Araghinejad, S., Hosseini-Moghari, S. M., Eslamian, S., 2017, Application of Data-Driven Models in Drought Forecasting, Ch. 23 in Handbook of Drought and Water Scarcity, Vol. 1: Principles of Drought and Water Scarcity, Ed. by Eslamian S. and Eslamian F., Francis and Taylor, CRC Press, USA, 423-440.

[168]Vafakhah, M., and Eslamian, S., 2017, Application of Intelligent Technology in Rainfall Analysis, Ch. 24 in Handbook of Drought and Water Scarcity, Vol. 1: Principles of Drought and Water Scarcity, Ed. by Eslamian S. and Eslamian F., Francis and Taylor, CRC Press, USA, 441-460.

[169]Vafakhah, M., Akbari Majdar, H. and Eslamian, S., 2017, Rainfall Prediction Using Time Series Analysis, Ch. 28 in Handbook of Drought and Water Scarcity, Vol. 1: Principles of Drought and Water Scarcity, Ed. by Eslamian S. and Eslamian F., Francis and Taylor, CRC Press, USA, 517-540.

[170]González, M. H., Garbarini, E. M., Rolla, A. L., and Eslamian, S., 2017, Meteorological Drought Indices: Rainfall Prediction in Argentina, Ch. 29 in Handbook of Drought and Water Scarcity, Vol. 1: Principles of Drought and Water Scarcity, Ed. by Eslamian S. and Eslamian F., Francis and Taylor, CRC Press, USA, 541-570.

[171]Hadizadeh, R. and Eslamian, S., 2017, Modeling Hydrological Process by ARIMA-GARCH Time Series, Ch. 30 in Handbook of Drought and Water Scarcity, Vol. 1: Principles of Drought and Water Scarcity, Ed. by Eslamian S. and Eslamian F., Francis and Taylor, CRC Press, USA, 571-590.

[172]Mujere, N., Yang, X. and Eslamian, S., 2017, Gradation of Drought-Prone Area, Ch. 31 in Handbook of Drought and Water Scarcity, Vol. 1: Principles of Drought and Water Scarcity, Ed. by Eslamian S. and Eslamian F., Francis and Taylor, CRC Press, USA, 591-606.

[173]Mahmudul Haque, M., Amir Ahmed, A., Rahman, A., Eslamian, S., 2017, Drought Losses to Local Economy, Ch. 33 in Handbook of Drought and Water Scarcity, Vol. 1: Principles of Drought and Water Scarcity, Ed. by Eslamian S. and Eslamian F., Francis and Taylor, CRC Press, USA, 627-642.

[174]Fakhruddin, B. S. H. M., Eslamian, S., 2017, Analysis of Drought Factors Affecting the Economy, Ch. 34 in Handbook of Drought and Water Scarcity, Vol. 1: Principles of Drought and Water Scarcity, Ed. by Eslamian S. and Eslamian F., Francis and Taylor, CRC Press, USA, 643-656.

[175]Dalezios, N. R., Eslamian, S., 2017, Environmental Impacts of Drought on Desertification Classification, Ch. 3 in Handbook of Drought and Water Scarcity, Vol. 2: Environmental Impacts and Analysis of Drought and Water Scarcity, Ed. by Eslamian S. and Eslamian F., Francis and Taylor, CRC Press, USA, 45-64.

[176]Nazif, S. and Tavakolifar, H., Eslamian, S., 2017, Climate Change Impact on Urban Water Deficit, Ch. 5 in Handbook of Drought and Water Scarcity, Vol. 2: Environmental Impacts and Analysis of Drought and Water Scarcity, Ed. by Eslamian S. and Eslamian F., Francis and Taylor, CRC Press, USA, 81-106.

[177]Shahid, S., Alamgir, M., Wang, X.-J., Eslamian, S., 2017, Climate Change Impacts on and Adaptation to Groundwater, Ch. 6 in Handbook of Drought and Water Scarcity, Vol. 2: Environmental Impacts and Analysis of Drought and Water Scarcity, Ed. by Eslamian S. and Eslamian F., Francis and Taylor, CRC Press, USA, 107-124.

[178] Orimoogunje, O. O. I., Eslamian, S., 2017, Minimizing the Impacts of Drought, Ch. 8 in Handbook of Drought and Water Scarcity, Vol. 2: Environmental Impacts and Analysis of Drought and Water Scarcity, Ed. by Eslamian S. and Eslamian F., Francis and Taylor, CRC Press, USA, 143-162.

[179]Maleksaeidi, H., Keshavarz, M., Karami, E., Eslamian, S., 2017, Climate Change and Drought: Building Resilience for an Unpredictable Future, Ch. 9 in Handbook of Drought and Water Scarcity, Vol. 2: Environmental Impacts and Analysis of Drought and Water Scarcity, Ed. by Eslamian S. and Eslamian F., Francis and Taylor, CRC Press, USA, 163-186.

[180]Reyhani, M. N., Eslamian, S., Davari, A., 2017, Sustainable Agriculture: Building Social-Ecological Resilience, Ch. 10 in Handbook of Drought and Water Scarcity, Vol. 2: Environmental Impacts and Analysis of Drought and Water Scarcity, Ed. by Eslamian S. and Eslamian F., Francis and Taylor, CRC Press, USA, 187 -204. 
[181]Crusberg, T. C., Eslamian, S., 2017, Drought and Water Quality, Ch. 11 in Handbook of Drought and Water Scarcity, Vol. 2: Environmental Impacts and Analysis of Drought and Water Scarcity, Ed. by Eslamian S. and Eslamian F., Francis and Taylor, CRC Press, USA, 205-218.

[182] Gaaloul, N., Eslamian, S., and Laignel, B., 2017, Contamination of Groundwater in Arid and Semiarid Lands, Ch. 16 in Handbook of Drought and Water Scarcity, Vol. 2: Environmental Impacts and Analysis of Drought and Water Scarcity, Ed. by Eslamian S. and Eslamian F., Francis and Taylor, CRC Press, USA, 291-314.

[183]Banjoko, B., Eslamian, S., 2017, Sanitation in Drought, Ch. 17 in Handbook of Drought and Water Scarcity, Vol. 2: Environmental Impacts and Analysis of Drought and Water Scarcity, Ed. by Eslamian S. and Eslamian F., Francis and Taylor, CRC Press, USA, 315-330.

[184]Davari, A., Bagheri, A., Reyhani, M. N., Eslamian, S., 2017, Environmental Flows Assessment in Scarce Water Resources, Ch. 18 in Handbook of Drought and Water Scarcity, Vol. 2: Environmental Impacts and Analysis of Drought and Water Scarcity, Ed. by Eslamian S. and Eslamian F., Francis and Taylor, CRC Press, USA, 331-352.

[185]Qian, Q., Eslamian, S., 2017, Streamflow Quality in Low-Flow Conditions, Ch. 20 in Handbook of Drought and Water Scarcity, Vol. 2: Environmental Impacts and Analysis of Drought and Water Scarcity, Ed. by Eslamian S. and Eslamian F., Francis and Taylor, CRC Press, USA, 375-386.

[186]Mohammadzade Miyab, N., Eslamian, S., Dalezios, N. R., 2017, River Sediment in Low Flow Condition, Ch. 21 in Handbook of Drought and Water Scarcity, Vol. 2: Environmental Impacts and Analysis of Drought and Water Scarcity, Ed. by Eslamian S. and Eslamian F., Francis and Taylor, CRC Press, USA, 387-408.

[187]Pérez-Blanco, C. D., Delacámara., G., Gómez., C. M., Eslamian, S., 2017, Crop Insurance in Drought Conditions, Ch. 23 in Handbook of Drought and Water Scarcity, Vol. 2: Environmental Impacts and Analysis of Drought and Water Scarcity, Ed. by Eslamian S. and Eslamian F., Francis and Taylor, CRC Press, USA, 423-444.

[188]Kahrizi, D., Esfahani, K., Ashraf Mehrabi, A., Ghaheri, M., Azizi Aram, Z., Khosravi, S., Eslamian, S., 2017, Biotechnology for Drought Improvement, Ch. 24 in Handbook of Drought and Water Scarcity, Vol. 2: Environmental Impacts and Analysis of Drought and Water Scarcity, Ed. by Eslamian S. and Eslamian F., Francis and Taylor, CRC Press, USA, 445-460.

[189]Wade, P., Eslamian, S., 2017, Water Issues from a System Dynamics Perspective, Ch. 25 in Handbook of Drought and Water Scarcity, Vol. 2: Environmental Impacts and Analysis of Drought and Water Scarcity, Ed. by Eslamian S. and Eslamian F., Francis and Taylor, CRC Press, USA, 461-488.

[190]Rahman, A., Hajani, E., Eslamian, S., 2017, Rainwater Harvesting in Arid Regions of Australia, Ch. 26 in Handbook of Drought and Water Scarcity, Vol. 2: Environmental Impacts and Analysis of Drought and Water Scarcity, Ed. by Eslamian S. and Eslamian F., Francis and Taylor, CRC Press, USA, 489-500.

[191]Dayani, S., Sabzalian, M. R., Hadipour, M. Eslamian, S., 2017, Water Scarcity and Sustainable Urban Green Landscape, Ch. 30 in Handbook of Drought and Water Scarcity, Vol. 2: Environmental Impacts and Analysis of Drought and Water Scarcity, Ed. by Eslamian S. and Eslamian F., Francis and Taylor, CRC Press, USA, 557-604.

[192]Gohari, A., Zareian, M. J., Eslamian, S., Nazari, R. 2017, Interbasin Transfers of Water: Zayandeh-Rud River Basin, Ch. 32 in Handbook of Drought and Water Scarcity, Vol. 2: Environmental Impacts and Analysis of Drought and Water Scarcity, Ed. by Eslamian S. and Eslamian F., Francis and Taylor, CRC Press, USA, 619-630.

[193]Banjoko, B., Eslamian, S., 2017, Environmental Evaluation: Lessons Learned from Case Studies, Ch. 33 in Handbook of Drought and Water Scarcity, Vol. 2: Environmental Impacts and Analysis of Drought and Water Scarcity, Ed. by Eslamian S. and Eslamian F., Francis and Taylor, CRC Press, USA, 631-664.

Citation: Dr. Kaveh Ostad-Ali-Askari et al. (2017). Investigation and Identification of Govkhoni Arg using Sat Light Images (Land Sat ETM+), International Journal of Mining Science (IJMS), 3(4), pp.64-80, DOI: http://dx.doi.org/ 10.20431/2454-9460.0304006.

Copyright: (C) 2017 Dr. Kaveh Ostad-Ali-Askari. This is an open-access article distributed under the terms of the Creative Commons Attribution License, which permits unrestricted use, distribution, and reproduction in any medium, provided the original author and source are credited 